\title{
SOME IMPRESSIONS OF THE PERMANENT APPELLATE JUDGES: 1958-2002
}

\author{
ILM Richardson*
}

In this article, the late Rt Hon Sir Ivor Richardson provides personal insight into the inner workings of the Court of Appeal and reflections on each of the judges appointed since its inception as a permanent appellate court in 1958 until 2002. Drawing on his vast experience as an advocate, as a judge and as a President of the Court of Appeal, Sir Ivor canvasses the Court as led by various judges: Gresson, North, Turner, McCarthy, Richmond, Woodhouse, Cooke and Sir Ivor himself. Sir Ivor retired as President of the Court of Appeal in 2002 after 25 years in judicial office. He wrote the bulk of the paper that forms this article in 2009, but it remained unfinished at the time of his death in 2014. The paper is reproduced here largely as it was written; only minor edits have been made for clarity.

\section{PREAMBLE}

The essays in The Permanent New Zealand Court of Appeal: Essays on the First 50 Years were presented as papers at the conference organised by the Legal Research Foundation held in Wellington on 14 March 2008. ${ }^{1}$ In speaking to my paper titled "The Permanent Court of Appeal: Surveying the 50 Years" I noted the obvious problems in writing a history essay. ${ }^{2}$ What to discuss? How best to do so? Whether to focus on particular participants, or events, or themes? Whether to try to be objective or, casting discretion to the winds, be frankly subjective? I explained that I wanted to focus on the Court as an institution over the 50 years and to produce a succinct paper but

* Sir Ivor Lloyd Morgan Richardson PCNZM QC (24 May 1930-29 December 2014). Sir Ivor sat on the Court of Appeal from 1977 until his retirement in 2002, for the last six years as President.

1 Rick Bigwood (ed) The Permanent New Zealand Court of Appeal: Essays on the First 50 Years (Hart Publishing, Oxford, 2009).

2 Ivor Richardson "The Permanent Court of Appeal: Surveying the 50 Years" in Rick Bigwood (ed) The Permanent New Zealand Court of Appeal: Essays on the First 50 Years (Hart Publishing, Oxford, 2009) 297. 
also to record some historical material. In the result the paper with its many appendices occupies 75 pages in the book of the conference.

The seven topics I dealt with were largely self-explanatory. The first covered the 50 years of discussion and steps taken leading to the first sitting of the newly-constituted Court on 17 February 1958. The second noted some major historical occasions in the life of the Court. The third drew on two snapshots of the functioning of the Court, one from 1980 and the other from the 1996 records. The fourth was a statistical analysis and comparison under various heads of the judgments delivered in 1960, 1970, 1980, 1990, 2000 and 2007. The fifth was designed to give a feel for some of the major cases from each decade. Two small groups formulated lists of particularly significant decisions: the nine judges' clerks at the Court in 2007 and, toward the other end of the time spectrum, 10 retired judges and two very experienced lawyers. Next, there were some comments on the oversight of the Court by the Privy Council and, from 2004, the Supreme Court. The seventh was a one page summing up.

As will be apparent from this preamble, the paper did not discuss particular judges, let alone give one insider's view of all the other judges, their personalities, qualities, attitudes, strengths and weaknesses. At the risk of seemingly removing the human factor, I preferred to focus on the work of the Court as a collegial institution, decade by decade, not being distracted by any attempt to rank the contribution of particular judges.

There were three further constraints. The first is the sheer number of judges over the 50 years: 11 Presidents, 23 other full-time permanent appellate judges, five Chief Justices ex-officio and more than 50 High Court judges sitting on secondment to divisions or for longer periods. Second, attempts at rankings often over-emphasise recent memory. Reflective history has the distressing habit of playing havoc with current assessments. In the paper I expressed the view that a decade or so of Supreme Court jurisprudence would be a better vantage point than today from which to review the oversight of the Court of Appeal by the Privy Council. In the same way there are benefits in waiting a decent interval after the glow or shadow of those who have recently exited has worn off. The third is my strong feeling that rounded assessments are best left to others not so directly involved themselves as I was.

Nevertheless, having been active in the profession during the whole of the 50 years and a member of the Court of Appeal for half that time, I think a contemporary perspective on the judges themselves could be of interest, even though naturally not the complete picture. Rather than undertaking a series of mini-biographical studies I will be sketching some personal recollections and impressions of the permanent appellate judges who preceded me and those with whom I sat. As happens, I appeared as counsel before all the judges of the first 20 years and came to know some of them quite well.

It is convenient to break the discussion down into seven periods: the Gresson years, the North years (including Turner's presidency of only 16 months), the McCarthy years, the Richmond years, 
the Woodhouse years, the Cooke years and the years I was President. Comprehensive biographical data for all the judges are readily available elsewhere, ${ }^{3}$ so I have not set out that material in these notes.

\section{THE GRESSON YEARS, 1958-1963}

I did not sit with any of the appellate judges of the Gresson years but argued several appeals from Invercargill where I was a young practitioner during that period. Commissioner of Inland Revenue $\mathrm{v}$ Walker was unusual. ${ }^{4}$ It was argued twice: first before the original court of Gresson $\mathrm{P}$, North and Cleary JJ when judgment was reserved; and then, after the death of Cleary J on 15 August 1962, before Gresson P, North J and the newly appointed Turner J. It soon became clear that Gresson P and North J had formed firm opposing views and the Solicitor-General, HRC Wild QC, and I found we were addressing our arguments for the Commissioner essentially to Turner J.

I also appeared in several cases before Barrowclough CJ when he came on circuit to Invercargill, but not in any appeals in Wellington. He was regarded as a courteous Judge and his careful judgments traversed all the points raised by counsel but without making any particular impression on me.

The original Gresson Court was a study in contrasts. Gresson P direct, at times gruff and wanting to get on with the case. He was always very respectful of precedent, particularly English appellate cases, and inclined to a strictly literal approach to statutory interpretation - not bad traits in the first President of a new Court in 1958. North J was very different, freely engaging with counsel, raising and testing arguments for the benefit of his own thinking. I found his judgments crisp and persuasively written. Cleary J, revered by the profession, was more enigmatic in Court, a slow and deep thinker willing just to listen to the arguments of counsel.

The Court had a modest workload in the early years (as reflected in the statistics collected in the conference paper), and neither Gresson P nor Cleary J had the opportunity to make a strong enduring mark in the relatively short periods they served on the Court. Turner J replaced Clearly $\mathbf{J}$ in 1962. In 1963, McCarthy J replaced Gresson P and North J was elevated to President.

\section{THE NORTH YEARS, 1963-1973 (INCLUDING TURNER J'S BRIEF PRESIDENCY)}

I was fortunate to appear in dozens of appeals over this period. In the first few years I was at the Crown Law Office when HRC Wild QC was Solicitor-General. Under his leadership Crown Law was invigorated and actively engaged in the work of the Crown. For me that included arguing cases all round the country and appearing every month in the Court of Appeal, mainly on criminal appeals

3 See for example Peter Spiller Court of Appeal of New Zealand 1958-1996: A History (Brookers, Wellington, 2002).

4 Commissioner of Inland Revenue $v$ Walker [1963] NZLR 339 (CA). 
and in the burgeoning world of tax. I continued to argue appeals in tax cases, for and against the Revenue, after I joined the Law Faculty at Victoria in 1967 and later, from 1973, a law partnership.

The North Court was always lively. You had to be on your mettle. Questions started coming, mainly from the President, almost as soon as you were on your feet. You were probed and tested. It was an adrenalin-charged intellectual challenge, a usually satisfying, often exhilarating and sometimes chastening experience

North P had had very wide practical experience in Christchurch, Ashburton, Hawera and Auckland, where he had made an immediate mark, and on the bench in Dunedin and Auckland before his appointment to the Court of Appeal. As a judge he seemed to have an instinctive understanding of human nature and a feeling for the just result, consistent with principle. The North Court was an impressive trio, due significantly to his personal qualities and leadership strengths and I felt his judgments reflected the emergence of a distinctive New Zealand law. His energy and directness are reflected vividly in his memoir, "Some Reminiscences of Sir Alfred North", not least in his discussion of various judicial appointments. ${ }^{5}$

Turner J, more intellectual and scholarly, was I thought over-shadowed in Court and in his judgments by the President. I felt that he was probably the most learned of the early judges but history may see his particular strengths and contribution to our laws being reflected more in his scholarly textbooks and General Editorship of Halsbury's Laws of New Zealand while in his long retirement years.

Like Sir Owen Woodhouse and Sir Clifford Richmond, McCarthy J was greatly influenced by the Depression years of the 1930s and his wartime experiences. He had an engaging personality. In the courtroom he was restless and energetic, and always involved. He was also much sought after by Governments as a perceptive thinker and safe pair of hands to undertake a wide range of major public inquiries. Occasionally I felt his judgments did not reflect the acuity and depth of perception which had come through in his questions and comments in argument.

Later I sat with him in a variety of appeals when he came back a number of times after his retirement. He was a lively, perceptive and down to earth contributor. His personality comes through in the note he prepared on his efforts to gain approval for the new Court of Appeal building. 6

\section{THE MCCARTHY YEARS, 1973-1976}

The three years of Sir Thaddeus' presidency were frustrating for him. Relations with the Chief Justice, Wild CJ, had become strained. Within the Court Richmond J had been appointed on North

5 Alfred North "Some Reminiscences of Sir Alfred North" (privately published, Auckland, 1980).

6 Richardson, above $\mathrm{n} 2$, at appendix C:2. 
P's retirement but there was a long hiatus following Turner P's retirement on 29 June 1973. Woodhouse $\mathbf{J}$ was presiding over the Australian Accident Compensation Inquiry at the request of both the Australian and New Zealand Prime Ministers. He was eventually appointed to the vacancy on 5 February 1974 but was not able to take up his appointment before July 1974. It meant that there was a succession of temporary short-term secondments from the Supreme Court and the Court of Appeal was less able to function during that time as an effective collegial body.

It is convenient to go straight to the five years of the Richmond presidency, which commenced in May 1976.

\section{THE RICHMOND YEARS, 1976-1981}

Sir Clifford Richmond was appointed President on 20 May 1976 following McCarthy P's retirement. Woodhouse $\mathrm{J}$ continued as the next senior and Cooke $\mathrm{J}$ was appointed to fill the vacancy the same day. I was appointed on 7 October 1977 when the permanent Court was increased to four judges, and McMullin J on 19 December 1979 when the permanent Court expanded to five. That bench continued under Sir Clifford's presidency until his retirement on 30 April 1981.

The new building, begun before McCarthy P retired, was still under construction when I joined the Court. The last time I sat in the old building in Balance Street was on 2 May 1980. Coincidentally it happened to be the third anniversary of my swearing in as a judge and the day I started keeping a short-lived journal of the working of the Court with some comments on the cases, judges and counsel. A few months later on 24 August 1980, I presented a paper at the Australasian Universities Law Schools Association Conference directed to the functioning of the Court, which was published in the Otago Law Review under the title "The Role of an Appellate Judge" and from which I drew in my 2008 paper surveying the 50 years of the permanent Court. ${ }^{7}$

In the early years we were not overly busy at the Court. The caseload was manageable, the hearings were much shorter than has become customary in recent years and, when we felt we could do so, we disposed of appeals on the day orally or from notes. The 1980 paper records that in 1979 80 per cent of the criminal appeals and about one half of the civil appeals were dealt with in that way. ${ }^{8}$ As a result we had much more time available for reserved judgments and to pursue other interests.

Richmond $\mathrm{P}$ was an all round lawyer, cautious when considering moving away from past precedents. He had an extraordinary capacity for delivering sometimes lengthy oral judgments reviewing the relevant facts, the arguments of counsel and the applicable legal principles comprehensively, referring only to the papers, cases and books in front of him. Often his oral delivery of judgment was slow and halting but his judgments always read well when transcribed.

7 Ivor Richardson "The Role of an Appellate Judge" (1981) 5 Otago LR 1.

8 At 3 . 
He also had the gift of maintaining a comfortable working environment with his fellow judges and in the courtroom where, as the 1980 paper notes, the judges tended to question counsel, often extensively, and freely discussed the facts and the law. ${ }^{9}$ But, unlike his contemporaries he seemed to be of another generation. And, despite his intellect and depth of knowledge of the law, he never struck me as having an inquiring mind and wide general interests, which I felt limited the breadth of his overall contribution.

\section{THE WOODHOUSE YEARS, 1981-1986}

Sir Owen Woodhouse became President on 1 May 1981 and Somers J was appointed the same day to fill the vacancy consequential on the retirement of Richmond P. Sir Owen retired early, five years later, to become first President of the Law Commission. There were no changes in the membership during the whole five years but the Court was augmented from time to time when Sir Clifford Richmond or Sir Thaddeus McCarthy sat for short periods and the Court also benefited from the regular secondment of Judges from the High Court.

At the time I regarded those years as particularly satisfying, and still do so. The Court was led by a generous and imaginative judge unaffected in his personal and working relationships by having become President. And, with their different experiences and qualities, my four colleagues were able to provide strength across all areas of the law. As in the Richmond Court, the permanent judges talked together in the ordinary course and did not meet for regularly scheduled meetings. But that did not seem to affect the effective functioning of the Court. The Court Office seemed to tick over. The only further appointments during the Richmond- and Woodhouse-led courts - McMullin and Somers JJ - had been anticipated and welcomed and the way we all worked meant that we were largely on top of the workload and flow of judgments.

Sir Owen had had by far the greatest range and depth of experiences shaping him as a lawyer through the Depression, wartime and post-war years. I felt that experience and his intellectual curiosity had given him a particular understanding of contemporary New Zealand. He was also a remarkable lateral thinker, a valuable quality in a lawyer and judge. Presiding in Court he moved cases along, sometimes disconcerting counsel with an elliptical comment on the issues followed by an enigmatic "You know what I mean". His own judgments reflected the thought he always put into their development and his careful choice of language. And, importantly as a good leader, he shared the judgment writing around both for cases dealt with on the day and those reserved.

Cooke $\mathbf{J}$ was always recognised for his intellect and his capacity for dealing with complex factual and legal issues apparently effortlessly. He had enjoyed a successful academic career as a research fellow at Cambridge and unusually for the times went directly to the bar on his return to Wellington becoming Queen's Counsel in 1964 at the early age of 38. He could be somewhat distant 
from immediate colleagues and his keenness in later years to take over as President caused some tensions. But he contributed greatly to the overall quality of the work of the Court over the five years.

McMullin and Somers JJ were most congenial colleagues. I had known them well for many years: Somers $\mathbf{J}$ since student days in Christchurch at a time when the total law student body was well under 100 and, apart from in the first year, we were all working in law offices; and McMullin J from when I went to the Crown Law Office and he was in the Crown Solicitor's firm in Hamilton. Because they were not so publicly visible after they left the Court in their early sixties, 20 years ago, to pursue other interests, I should say something more about their respective backgrounds and their post-retirement lives.

Somers $\mathbf{J}$ was a very learned lawyer over the whole field of law and was particularly renowned as an expert on equity and property, on which he had lectured at Canterbury for 20 years before his appointment to the bench in 1974. He had been on the panel of Crown prosecutors in Christchurch and so had no difficulty in presiding over criminal trials, as he demonstrated in the massive fraud trial following the collapse of the Jeffs Brothers' commercial empire. ${ }^{10}$ His all-round strengths were reflected in his judgments.

Following his retirement from the Court in 1990 he chaired a thankless inquiry into nuclear propelled ship visits, was engaged as an arbitrator in London arbitrations, sat in the Hong Kong Court of Final Appeal and on the Bloody Sunday Inquiry in Northern Ireland and immersed himself in his Christchurch interests, particularly racing and rhododendrons.

McMullin J was as energetic and outgoing in his Wellington years as he had been working in Hamilton, initially as a qualified lawyer, soon after as partner in the Crown firm, and then as a barrister. He soon made a mark in the wider profession, speaking at three New Zealand Law Society Triennial Conferences. He was appointed a judge at Auckland in 1970 at the early age of 43 and to the Court of Appeal during the Richmond years.

As an appellate judge he always brought to the work an awareness of the practicalities, instinct for the right answer, and commercial nous, so important in helping ultimate assessments of cases. Following his retirement from the Court in April 1989, he was in immediate demand as an arbitrator and for a succession of Government appointments, while at the same time pursuing his long suppressed interest in farming.

\section{THE COOKE YEARS, 1986-1996}

Casey J, who had been waiting in the wings, was appointed permanently to the Court on 6 May 1986 following Woodhouse P's retirement and served until his own retirement on 28 August 1995. Cooke $\mathrm{P}$ was appointed President on the same day. Bisson $\mathrm{J}$ was appointed as the sixth permanent

$10 \quad R v$ Jeffs [1978] 1 NZLR 441 (CA). 
judge on 1 February 1987 and retired on 23 November 1990. In the meantime McMullin J retired on 30 April 1989 and Somers J followed on 19 December 1990. Hardie Boys J was appointed in place of McMullin J on 1 May 1989 and retired on 23 February 1996 to become Governor-General, a week after Cooke P's resignation took effect following his elevation to the peerage of the United Kingdom. The vacancies created by the retirements of Bisson $\mathbf{J}$ and Somers $\mathbf{J}$ had been filled by the appointments of Gault J on 5 February 1991 and McKay J on 28 May 1991. Finally, on 12 August 1995 Henry J was appointed to the vacancy created by the retirement of Casey J, and Thomas J was appointed to the new seventh permanent position.

The large number of challenging cases and the increasing workload made these years fascinating. But I found them less than wholly satisfying. I felt that, for all his intellectual gifts, Cooke P did not enable his colleagues to work comfortably together with him in an effectively functioning Court and, as a collegial group, drawing on their differing strengths. On the contrary, having led from the front he seemed to expect others should rationally follow.

Turning, first, to basic management and reflecting his personalised approach to the running of the Court, the President was often oblivious to the need for the Court to start regularly at the scheduled time - as Sir Michael Hardie Boys noted in the eulogy he gave at the President's funeral. ${ }^{11} \mathrm{He}$ could often keep counsel, litigants, fellow Judges and others present at Court waiting frustratingly for half an hour or more without explanation. Sir Michael Hardie Boys also observed that, despite all his good qualities, "[a]s a colleague Robin Cooke was at times difficult, at times frustrating, at times infuriating. He was no administrator. He detested meetings". ${ }^{12}$ And, so, we could never persuade him to have regular meetings to review the progress of the increasing numbers of cases on hand or the more complex functioning of the Court.

More importantly, while we continued to dispose of straightforward cases on the day, reserved decisions could languish for months and there was little give and take when anyone sought some change to his drafts. Basically he wanted his own way and worked more comfortably with judges who tended to think along the same lines or to generally follow his lead. This led at times to severe tensions. For example, when several cases under the New Zealand Bill of Rights Act 1990, which set the early very liberal tone, had come before three judge courts he presided over and were later reversed or modified by five or seven judge courts; ${ }^{13}$ or when appointments to the Court were discussed with the Attorney-General and his wishes were not acceded to.

11 Michael Hardie Boys "The Right Honourable the Lord Cooke of Thorndon" (2008) 39 VUWLR 9.

12 At 9 .

13 See for example $R v$ Grayson [1997] 1 NZLR 399 (CA). 
Regrettably I felt that over the years he tended to isolate himself from most of his colleagues. We plugged along but it was not a comfortable working environment. He was very talented as a judge but, however it may have appeared to the outside world, I felt he was inadequate as President.

By mid-1986 McMullin and Somers JJ had served many years on the High Court and then the Court of Appeal. As I noted when commenting on the Woodhouse years, they were most congenial colleagues with great strengths. They continued as engaged collegial colleagues until they retired in their early sixties to pursue other interests.

Casey $\mathrm{J}$ had practised in Lower Hutt, Blenheim and then for 24 years in a major Auckland legal firm, followed by 12 years on the bench in Christchurch and latterly Auckland before his appointment to the Court of Appeal. He was an all-rounder: energetic, inquiring, thoughtful, down to earth and an interesting blend of liberal and conservative. I appreciated that he was always on top of his cases in the courtroom and up to date in his judgments. I felt he dealt comfortably with complex problems in any area and willingly did more than his fair share of the most difficult criminal appeals. And as a colleague he was amenable to argument and always pleasant.

Bisson J came to the Court in February 1987 following illustrious service in the navy in the Second World War, a long period in private practice in Hawke's Bay and nine years on the High Court bench in Hamilton. On the Court he was always courteous and was an equable colleague. His judgments were careful and moderate. In his relatively short time on the Court he was, I felt, inclined by nature to follow the President's lead.

Hardie Boys J's general practice in Wellington had not involved substantial litigation experience. But, in his nine years on the High Court in Christchurch he had demonstrated his allround capability. He had a keen analytical mind and superb writing skills and his judgments reflected the depth of thought and care he gave to them. As well, he had a naturally sunny disposition, always a plus in working relationships.

McKay $\mathrm{J}$ was generally considered the leader of the practising profession at the time of his direct appointment to the Court at the age of 62 on 28 May 1991, retiring on 7 March 1997. He had elected to stay in his firm instead of going to the separate bar. His practice ranged from commercial litigation and advisory work to arbitration, and he had taken leading roles in many professional bodies. He was a hard-working member of the Court with a fairly conservative approach to judging. He freely drew on his vast experience, but I felt he came to the bench rather late to adjust to the collegial involvement.

Although appointed just before McKay J, Gault J continued as a permanent appellate judge until he retired early from the Supreme Court in 2006 to move on to other challenges. I tend to identify him more with the post-Cooke years and include him in the next section of these reflections covering the years I was President, along with Henry and Thomas JJ who served only very briefly at the end of the Cooke years. 


\section{MY PRESIDENTIAL YEARS, 1996-2002: THE CHANGES}

I was appointed President in December 1995 to take effect on 17 February 1996 following Cooke P's formal retirement the previous day. In consultation with the Department for Courts, the continuing judges (Gault, McKay, and Henry JJ and Thomas $\mathrm{J}$ who had been appointed on 12 August 1995 - but not including Hardie Boys J who was Governor-General designate and had taken up his earlier planned stint on the Privy Council) and I began planning the organisation of the projected workload for 1996 and the much needed reorganisation of the systems and procedures of the Court. That led, among other changes, to new practice notes for civil and criminal appeals, new rules to replace the outdated Court of Appeal Rules 1955 and Criminal Appeal Rules 1946, and to the introduction of active case flow management, all involving extensive consultation with the Bar Association and the New Zealand Law Society.

The Court ceased sitting on Friday, which was reserved for discussing judgments, working on judgments, reading ahead, and for the monthly meeting of the permanent judges, including the Chief Justice. As Sir Thomas Eichelbaum noted in his essay "The Courts: An Era of Change", when Sir Ronald Davison was about to retire there were differing views about whether the Chief Justice should be based in the Court of Appeal or should stay in the High Court with "a good deal of lobbying on the issue". ${ }^{14}$ Unfortunately tensions continued unabated on Cooke P's part after Sir Thomas was appointed Chief Justice. The Chief Justice elected to deal with the stand-off by focusing on the Criminal Appeal Division provided for in statutory form by the Judicature Amendment Act 1991, which was eventually dealing with around 80 per cent of criminal appeals.

Because of the need for forward planning for the allocation of High Court and Court of Appeal judges to divisional criminal and civil courts, which judges were available each week was largely settled several months ahead. It was then the court office's responsibility to allocate cases to divisional courts as the fixtures were sought. The finalising of the sitting programme each month followed the processes adopted by the permanent appeal judges. The draft allocation of the cases by the President with the next senior judge (and with their draft being circulated for comment to the other judges) was essentially driven by the resources available at the time. ${ }^{15}$ I mention that development because occasionally commentators assume that presiding judges stack the Court with amenable colleagues.

The vacancies created by the retirements of Cooke P and Hardie Boys $\mathrm{J}$ were filled by the appointments on 8 February 1996 of Keith J to commence on 1 April 1996 and Blanchard J to

14 Thomas Eichelbaum "The Courts: An Era of Change" in Ian Barker and G Wear (eds) Law stories: Essays on the New Zealand Legal Profession 1969-2003 (LexisNexis, Wellington, 2003) 1 at 7.

15 See NZJPIL's Special Issue on New Zealand Centre for Public Law's First Annual Conference on the Primary Organs of Government, particularly Ivor Richardson "Closing Remarks" (2004) 2 NZJPIL 115 at $119-120$. 
commence on 15 April 1996. Tipping J was appointed to replace McKay J on 1 June 1997. Henry J retired on 3 July 2000 and was replaced by the then Solicitor-General, JJ McGrath QC. Finally, Thomas J retired on 12 September 2001 and was replaced by Anderson J.

\section{MY PRESIDENTIAL YEARS: IMPRESSIONS OF THE JUDGES}

In his early career Gault $\mathbf{J}$ specialised in intellectual property and was admitted as a patent attorney as well as barrister and solicitor. He was partner in a specialist Wellington law firm for 20 years where he soon became a recognised leader and then made a significant mark internationally in the rapidly expanding specialty. He went to the commercial Bar in 1981. In quick succession he was appointed QC in 1984, High Court Judge in December 1987 and to the Court of Appeal on 5 February 1991.

I felt he had a particular ability to distil and simplify complex issues in any area of the law. On the Court he was careful, reflective and low-key, without any soaring flights of imagination or histrionics. Whether or not I agreed, I felt his conclusions were always soundly thought through. He always did his share of the wider work of the Court and I found him a particularly congenial colleague.

Henry $\mathbf{J}$ made a remarkable contribution to the Court. That was no surprise given his qualities, expertise and experience. In practice in Auckland both in his firm and at the Bar he had an extraordinary range of work: common law, public law and criminal law. His standing and capacity for work in other fields had led to his appointment to the Contracts and Commercial Law Committee and to the Rules Committee as well as to his presidency of both the Medico-Legal Society and the Auckland District Law Society. In his 11 years on the High Court he demonstrated the same qualities. He seemed to do far more than his share of particularly difficult cases. He was automatic choice for appointment to the Commercial List at its inception in 1987, to the Criminal Appeal Division in 1991 and to the sometimes fraught position of Executive Judge at Auckland.

I felt he had a particular aptitude for identifying crucial issues and seeking a principled answer to the particular problem, reflected in the searching questions he asked counsel at the hearing of appeals - sometimes to the discomfort of woolly thinking - and, in a world where it seems easier to write at length than shortly, he had the ability to reduce cases to the essentials and to write economically. By nature a thoughtful conservative, as a colleague on the Court he was conscientious and equable, always contributing to the collegial discussion of cases, to the organisational work of the Court and to the ease of social relationships.

Thomas $\mathbf{J}$ made a distinctive contribution to the work of the Court with the same commitment and energy, and at times flamboyance, he had shown in his early career. At Victoria he was a renowned debater. He soon became a leading practitioner in Auckland. He was a major force in the development of Russell McVeagh and was senior common law partner for 14 years before he went to the separate Bar. He was active in the profession serving as president of the Auckland District Law Society, chair of the New Zealand Disciplinary Tribunal and a leading promoter and 
foundation president of the New Zealand Bar Association. His intellectual curiosity and engagement in the challenge of ideas were reflected in his taking off to Harvard for a full academic year in his early forties and his willingness to speak at law schools and law conferences.

In his five years on the High Court bench and six years on the Court of Appeal he demonstrated those same qualities. He always set high standards for himself, maintaining his own timetable for completing his judgments and particularly immersed himself in cases, often high profile, which involved substantial public policy issues on which he strongly advanced his own perspectives. That led at times to exasperation, mini-crises and turbulence in relationships. But, whatever the outward appearance, and perhaps surprisingly, those instances affected only a tiny minority of the cases. The reality was that the Court never had fewer dissents than in those years, from six per cent in 1960 reducing to two per cent in 2000 . Contrary to what at times has been suggested Thomas $\mathrm{J}$ was not a frequent dissenter. In those six years he sat on 900 substantive cases and wrote judgments in around 350 , delivering some 30 dissenting judgments in all, that is, in about three per cent of his cases. We always discussed all the cases amongst ourselves after the hearing and progressively as we were circulating our drafts. And over those years we all participated in the social life of the Court and enjoyed each others company.

Keith $\mathbf{J}$ was appointed directly to the Court without having had any significant experience as a judge or practitioner in New Zealand, but he had already carved out a remarkable academic, governmental and international career. Educated at Auckland (LLB) he served briefly in the Department of External Affairs before being appointed to the Law School at Victoria, where he rose to become Professor (and Dean for four years). He then went to the Law Commission when it was set up in 1981, and in 1986 he succeeded Sir Owen Woodhouse as President. Earlier he had completed an LLM at Harvard, spent two years at the United Nations Secretariat in New York and two years as Executive Director of the New Zealand Institute of International Affairs. As a public law expert he had been very involved in the functioning of Government including the preparation of the Cabinet Manual, in the Legislation Advisory Committee and as a member of both the Official Information Inquiry and the Royal Commission on Electoral Reform. He also held advising and leadership positions in international and human rights laws, including all the steps that led to the enactment of the New Zealand Bill of Rights 1990, and membership of various Pacific Islands Courts of Appeal and international bodies.

It was not easy for Keith $\mathrm{J}$ to move comfortably through the unfamiliar (for him) mass of criminal and civil appeals and practical litigation questions that were part of the remorselessly busy daily round. Against that, I felt it was very helpful to have him as a member of the Court over those years when we were grappling with such an expanding range of international law, human rights law and public law issues. As well, we all benefited from the network of expertise that he brought to the task, even though our regular work flow found it hard to cope with his demanding personal schedule of overseas engagements. It was also valuable to have such a thoughtful walking encyclopaedia amongst us. 
Blanchard J was also an unconventional appointment. Another very talented product of Auckland Law Faculty and Harvard Law School, he had gone into commercial law practice where he combined acting for the big guns in the Auckland business world, and also being a director of major public companies, with distinguished authorship of property and commercial law texts, and part time membership of the Law Commission and Waitangi Tribunal.

Almost starting from scratch, he seemed to adjust effortlessly to the work of a trial judge and was appointed to the Court of Appeal after less than four years in that role. On the Court the breadth of his expertise and experience was an obvious plus and I felt he dealt comfortably and logically with complex problems in any area. As a colleague he was hard-working and organised, he could be relied on to produce careful drafts for consideration by the other Judges remarkably quickly and, with Henry J, was particularly involved in the updating of the Rules and processes governing the functioning of the Court. I found him a pleasant and likeable colleague.

Born the same month as Blanchard J, Tipping J's career had followed a very different path. He came to Christchurch from England in 1957. He was a star student at Canterbury, graduating BA, LLB and LLM, and winning the Gold Medal in Law and (nationally) the Sir Timothy Cleary Memorial Prize. He was one of several outstanding common law partners in a Christchurch law firm for 20 years before appointment to the High Court in 1986. On the side he taught in several law subjects at the Law School and was actively involved in the profession, being President of the Canterbury District Law Society and chair of the New Zealand Courts and Tribunals Committee. In 11 years on the High Court he was trial judge in many of the high profile, unusual cases which seemed to congregate in Christchurch and displayed all-round strengths in the South Island circuit.

Tipping J came to the Court of Appeal in 1997 brimful of enthusiasm and experience. He was always cheerful and outgoing and I felt his intellectual skills and long experience as a trial judge enabled him to get on top of all his cases and contribute substantially to their resolution. He added significantly to the collegiality of the Court over the years we sat together.

McGrath J practised in Wellington for 14 years before going to the bar in 1984, being appointed QC in 1988 and Solicitor-General the following year. As a young practitioner his wider abilities were recognised by his appointment as Joint Secretary of the New Zealand Law Society Triennial Conference held in Wellington in 1975, a major legal event in those days. He had also been active in student affairs at Victoria where he graduated LLB and LLM, and was President of the Victoria Students Association and then full-time President of the New Zealand University Students Association in 1968. For 20 years he was a member of the Council of Victoria. He succeeded me as Chancellor in 1986, resigning when appointed Solicitor-General.

In his 11 years as Solicitor-General he gained the confidence of both Ministers in successive administrations and of senior public servants. I felt that was because of his leadership qualities in building up the Crown Law Office, where he attracted and promoted talented young men and women to work as lawyers in the challenging world of the 1990s. It was also because of his 
understanding of the functioning of government and instinctive awareness of the realities of decision making, as well as through his representation of the Crown in the courts where he led in key cases and ensured that the Crown was well represented in litigation throughout the country.

McGrath J brought particular strengths to the Court and was the obvious choice for appointment on Henry J's retirement. Sensibly, I thought, he took his own time settling in to his new role and I felt that the work of the Court gained significantly from the way he approached all his cases and particularly from his experience, nous and understanding of public policy implications and governance practicalities.

Anderson $\mathbf{J}$ was appointed in place of Thomas $\mathbf{J}$. He had been active in student affairs and in debating and mooting at Auckland and after a short period in private practice had gone to the separate bar in his late 20s. He was appointed QC in 1986 and to the High Court in 1987 at age 43, initially at Hamilton and then at Auckland. By 2001 he was the senior High Court Judge in the country and had had immense experience of criminal jury trials which had seldom led to successful appeals.

In the few months we sat together I found him a pleasant and willing colleague, not inclined to intervene in the hearing of appeals and thoughtful in collegial discussion. 